\title{
Validation List no. 127 \\ List of new names and new combinations previously effectively, but not validly, published
}

\author{
Correspondence \\ Jean Euzéby \\ email address can be found at \\ www.bacterio.net
}

\begin{abstract}
The purpose of this announcement is to effect the valid publication of the following effectively published new names and new combinations under the procedure described in the

Bacteriological Code (1990 Revision). Authors and other individuals wishing to have new names and/or combinations included in future lists should send three copies of the pertinent reprint or photocopies thereof, or an electronic copy of the published paper, to the IJSEM Editorial Office for confirmation that all of the other requirements for valid publication have been met. It is also a requirement of IJSEM and the ICSP that authors of new species, new subspecies and new combinations provide evidence that types are deposited in two recognized culture collections in two different countries. It should be noted that the date of valid publication of these new names and combinations is the date of publication of this list, not the date of the original publication of the names and combinations. The authors of the new names and combinations are as given below, and these authors' names will be included in the author index of the present issue. Inclusion of a name on these lists validates the publication of the name and thereby makes it available in bacteriological nomenclature. The inclusion of a name on this list is not to be construed as taxonomic acceptance of the taxon to which the name is applied. Indeed, some of these names may, in time, be shown to be synonyms, or the organisms may be transferred to another genus, thus necessitating the creation of a new combination.
\end{abstract}

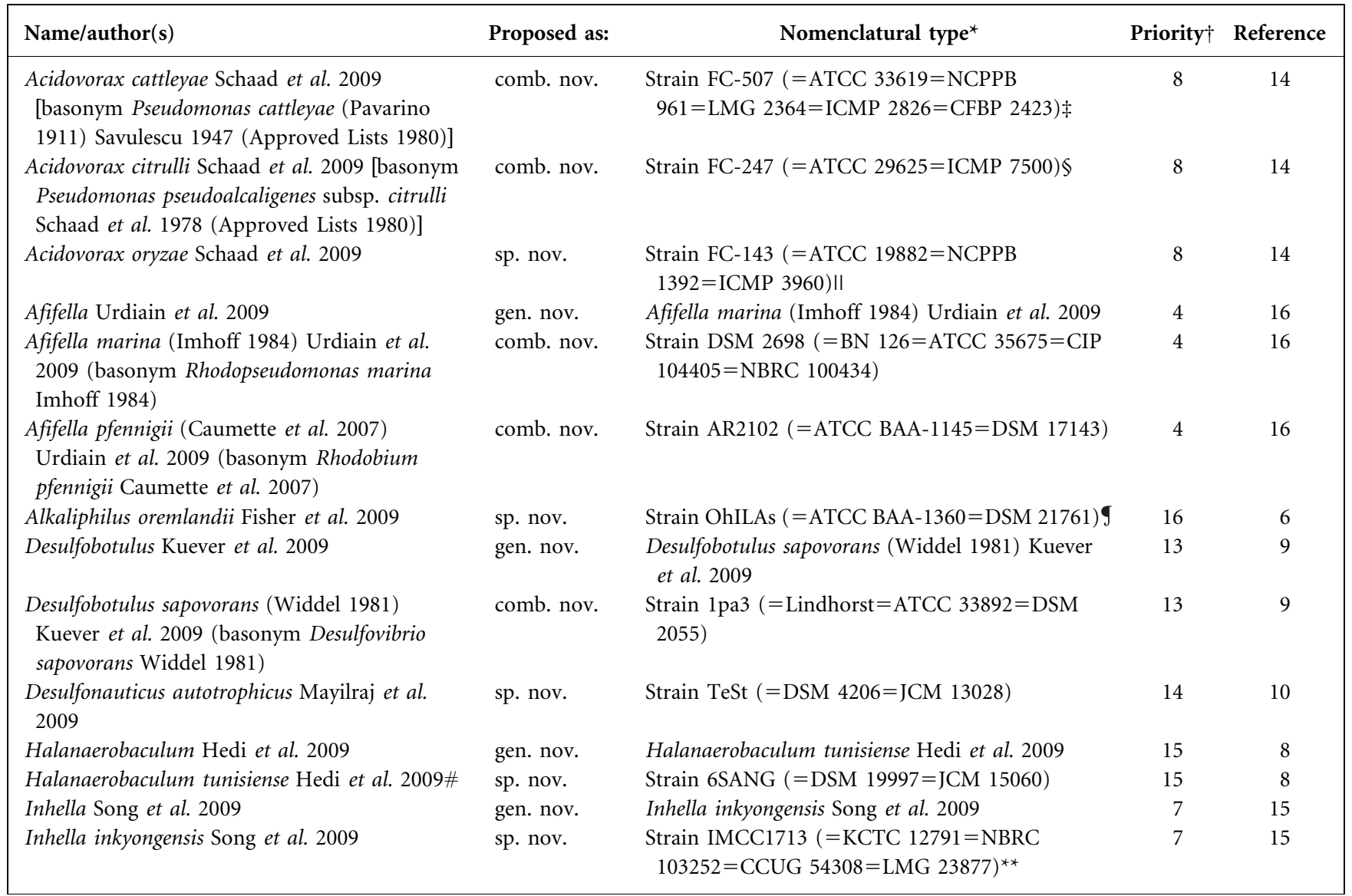


cont.

\begin{tabular}{|c|c|c|c|c|}
\hline Name/author(s) & Proposed as: & Nomenclatural type ${ }^{\star}$ & Priority $\dagger$ & Reference \\
\hline Lactobacillus tucceti Chenoll et al. 2009 & sp. nov. & Strain R 19c (=DSM 20183=CECT 5920) & 1 & 5 \\
\hline Luteimonas aestuarii Roh et al. 2009 & sp. nov. & Strain B9 (=KCTC 22048=DSM 19680) & 5 & 11 \\
\hline $\begin{array}{l}\text { Prosthecomicrobium consociatum Vasil'eva et al. } \\
2009\end{array}$ & sp. nov. & Strain $11(=$ VKM B-2498=CCM 7594)†† & 2 & 17 \\
\hline $\begin{array}{l}\text { Prosthecomicrobium mishustinii Vasil'eva et al. } \\
2009\end{array}$ & sp. nov. & Strain $17(=$ VKM B-2499=CCM 7569)㧊 & 2 & 17 \\
\hline Rhodobaca barguzinensis Boldareva et al. 2009\$\$ & sp. nov. & Strain alga-05 (=VKM B-2406=DSM 19920)IIII & 3 & 2 \\
\hline Roseinatronobacter monicus Boldareva et al. 2009 & sp. nov. & Strain ROS 35 (=VKM B-2404=DSM 18423) 99 & 6 & 3 \\
\hline Roseococcus suduntuyensis Boldareva et al. 2009 & sp. nov. & Strain SHET (=VKM B-2453=DSM 19979) & 10 & 4 \\
\hline $\begin{array}{l}\text { Thermodesulfovibrio hydrogeniphilus Haouari } \\
\text { et al. } 2009\end{array}$ & sp. nov. & Strain Hbr5 (=DSM 18151=JCM 13991) & 12 & 7 \\
\hline Thioalkalibacter Banciu et al. 2009 & gen. nov. & Thioalkalibacter halophilus Banciu et al. 2009 & 9 & 1 \\
\hline Thioalkalibacter halophilus Banciu et al. 2009 & sp. nov. & $\begin{array}{l}\text { Strain ALCO } 1 \text { (=UNIQEM U263= NCCB } \\
\text { 100269)\#\# }\end{array}$ & 9 & 1 \\
\hline $\begin{array}{l}\text { Xylella fastidiosa subsp. fastidiosa Wells et al. } \\
\text { 1987*** }\end{array}$ & subsp. nov. & Strain ATCC 35879 (=ICMP 15197)††† & 11 & 12,13 \\
\hline $\begin{array}{l}\text { Xylella fastidiosa subsp. multiplex Schaad et al. } \\
2004\end{array}$ & subsp. nov. & Strain ATCC 35871 (=ICMP 15199)抹 & 11 & 12,13 \\
\hline
\end{tabular}

For references to Validation Lists 1-71, see Int J Syst Bacteriol 49 (1999) 1325. Lists 72-126 were published in Int J Syst Evol Microbiol 50 (2000) 3, 423, 949, 1415, 1699, 1953; and 51 (2001) 1, 263, 793, 1229, 1619, 1945; and 52 (2002) 3, 685, 1075, 1437, 1915; and 53 (2003) 1, 373, 627, 935, 1219, 1701; and 54 (2004) 1, 307, 631, 1005, 1425, 1909; and 55 (2005) 1, 547, 983, 1395, 1743, 2235; and 56 (2006) 1, 499, 925, 1459, 2025, 2507; and 57 (2007) 1, 433, 893, 1371, 1933, 2449; and 58 (2008) 1, 529, 1057, 1511, 1993, 2471; and 59 (2009) 1, 451.

${ }^{\star}$ Abbreviations of culture collections cited in this list can be found at http://ijs.sgmjournals.org/misc/collections.dtl $\dagger$ Priority number assigned according to the date the documentation and request for validation are received.

$\ddagger$ The culture collection accession numbers ICPB 30134 (PC21) and IBSBF 209 are also cited in the effective publication, but the authors did not provide evidence that the type strain is deposited in these collections.

\$The culture collection accession numbers ICPB 30064 and IBSBF 1851 are also cited in the effective publication, but the authors did not provide evidence that the type strain is deposited in these collections.

IIThe culture collection accession number ICPB 30003 (PS 177) is also cited in the effective publication, but the authors did not provide evidence that the type strain is deposited in this collection.

In the effective publication, strain ATCC BAA-1360 is cited as BAA1360. The culture collection accession number DSM 21761 has been provided on request for validation.

\#The specific epithet tunisiense is a N.L. neut. adj., not a N.L. neut. n. as cited in the effective publication.

${ }^{* *}$ The culture collection accession number LMG 23877 has been provided on request for validation.

$\dagger \dagger$ The culture collection accession numbers VKM B-2498 and CCM 7594 have been provided on request for validation.

\$ The culture collection accession numbers VKM B-2499 and CCM 7569 have been provided on request for validation.

$\$ \$$ The etymology of the specific epithet must be the following: bar.gu.zi.nen'sis. N.L. fem. adj. barguzinensis pertaining to Barguzin Valley, where the type strain was isolated.

IIIIIn the effective publication, the type strain VKM B-2406 is cited as VKM B2406, and strain DSM 19920 is cited as DSMZ 19920.

ISThe culture collection accession number DSM 18423 has been provided on request for validation. The culture collection accession number UNIQEM U-251 is also cited in the effective publication, but the authors did not provide evidence that the type strain is deposited in this collection. \#\#The culture collection accession number NCCB 100269 has been provided on request for validation. The culture collection accession number DSM 19224 is also cited in the effective publication, but the authors did not provide evidence that the type strain is deposited in this collection. ${ }^{* * \star}$ The correct subspecific epithet was provided by the way of an erratum.

$\dagger \dagger \dagger$ The culture collection accession number ICPB 50025 is also cited in the effective publication, but the authors did not provide evidence that the type strain is deposited in this collection.

$\$ \neq \ddagger$ The culture collection accession number ICPB 50039 is also cited in the effective publication, but the authors did not provide evidence that the type strain is deposited in this collection. 


\section{References}

1. Banciu, H. L., Sorokin, D. Y., Tourova, T. P., Galinski, E. A., Muntyan, M. S., Kuenen, J. G. \& Muyzer, G. (2008). Influence of salts and $\mathrm{pH}$ on growth and activity of a novel facultatively alkaliphilic, extremely salt-tolerant, obligately chemolithoautotrophic sufur-oxidizing Gammaproteobacterium Thioalkalibacter halophilus gen. nov., sp. nov. from South-Western Siberian soda lakes. Extremophiles 12, 391-404.

2. Boldareva, E. N., Akimov, V. N., Boychenko, V. A., Stadnichuk, I. N., Moskalenko, A. A., Makhneva, Z. K. \& Gorlenko, V. M. (2008). Rhodobaca barguzinensis sp. nov., a new alkaliphilic purple nonsulfur bacterium isolated from a soda lake of the Barguzin Valley (Buryat Republic, Eastern Siberia). Microbiology (English translation of Mikrobiologiia) 77, 206-218.

3. Boldareva, E. N., Bryantseva, I. A., Tsapin, A., Nelson, K., Sorokin, D. Yu., Tourova, T. P., Boichenko, V. A., Stadnichuk, I. N. \& Gorlenko, V. (2007). The new alkaliphilic bacteriochlorophyll $a$ containing bacterium Roseinatronobacter monicus sp. nov. from the hypersaline soda Mono Lake (California, United States). Microbiology (English translation of Mikrobiologiia) 76, 82-92.

4. Boldareva, E. N., Tourova, T. P., Kolganova, T. V., Moskalenko, A. A. Makhneva, Z. K. \& Gorlenko, V. M. (2009). Roseococcus suduntuyensis sp. nov., a new aerobic bacteriochlorophyll $a$-containing bacterium isolated from a low-mineralized soda lake of Eastern Siberia. Microbiology (English translation of Mikrobiologiia) 78, 92-101.

5. Chenoll, E., Macián, M. C. \& Aznar, R. (2006). Lactobacillus tucceti sp. nov., a new lactic acid bacterium isolated from sausage. Syst Appl Microbiol 29, 389-395.

6. Fisher, E., Dawson, A. M., Polshyna, G., Lisak, J., Crable, B., Perera, E., Ranganathan, M., Thangavelu, M., Basu, P. \& Stolz, J. F. (2008). Transformation of inorganic and organic arsenic by Alkaliphilus oremlandii sp. nov. strain OhILAs. Ann N Y Acad Sci 1125, 230-241.

7. Haouari, O., Fardeau, M.-L., Cayol, J.-L., Fauque, G., Casiot, C., Elbaz-Poulichet, F., Hamdi, M. \& Ollivier, B. (2008). Thermodesulfovibrio hydrogeniphilus sp. nov., a new thermophilic sulphate-reducing bacterium isolated from a Tunisian hot spring. Syst Appl Microbiol 31, 38-42.

8. Hedi, A., Fardeau, M.-L., Sadfi, N., Boudabous, A., Ollivier, B. \& Cayol, J.-L. (2009). Characterization of Halanaerobaculum tunisiense gen. nov., sp. nov., a new halophilic fermentative, strictly anaerobic bacterium isolated from a hypersaline lake in Tunisia. Extremophiles 13, 313-319.

9. Kuever, J., Rainey, F. A. \& Widdel, F. (2005). Genus IV. Desulfobotulus gen. nov. In Bergey's Manual of Systematic
Bacteriology, 2nd edn, vol. 2 (The Proteobacteria), part C (The Alpha-, Beta-, Delta-, and Epsilonproteobacteria), pp. 970-971. Edited by D. J. Brenner, N. R. Krieg, J. T. Staley \& G. M. Garrity. New York: Springer.

10. Mayilraj, S., Kaksonen, A. H., Cord-Ruwisch, R., Schumann, P., Spröer, C., Tindall, B. J. \& Spring, S. (2009). Desulfonauticus autotrophicus sp. nov., a novel thermophilic sulfate-reducing bacterium isolated from oil-production water and emended description of the genus Desulfonauticus. Extremophiles 13, 247255.

11. Roh, S. W., Kim, K.-H., Nam, Y.-D., Chang, H.-W., Kim, M.-S., Yoon, J.-H., Oh, H.-M. \& Bae, J.-W. (2008). Luteimonas aestuarii sp. nov., isolated from tidal flat sediment. J Microbiol 46, 525529.

12. Schaad, N. W., Postnikova, E., Lacy, G., Fatmi, M \& Chang, C.-J. (2004). Xylella fastidiosa subspecies: X. fastidiosa subsp. piercei, subsp. nov., $X$. fastidiosa subsp. multiplex subsp. nov., and $X$. fastidiosa subsp. pauca subsp. nov. Syst Appl Microbiol 27, 290300.

13. Schaad, N. W., Postnikova, E., Lacy, G., Fatmi, M \& Chang, C. J. (2004). Erratum. The title should read as follows: Xylella fastidiosa subspecies: $X$. fastidiosa subsp. fastidiosa, subsp. nov., $X$. fastidiosa subsp. multiplex subsp. nov., and X. fastidiosa subsp. pauca subsp. nov. Syst Appl Microbiol 27, 763.

14. Schaad, N. W., Postnikova, E., Sechler, A., Claflin, L. E., Vidaver, A. K., Jones, J. B., Agarkova, l., Ignatov, A., Dickstein, E. \& Ramundo, B. A. (2008). Reclassification of subspecies of Acidovorax avenae as A. Avenae (Manns 1905) emend., A. cattleyae (Pavarino, 1911) comb. nov., A. citrulli Schaad et al., 1978) comb. nov., and proposal of A. oryzae sp. nov. Syst Appl Microbiol 31, 434-446.

15. Song, J., Oh, H.-M., Lee, J.-S., Woo, S.-B. \& Cho, J.-C. (2009). Inhella inkyongensis gen. nov., sp. nov., a new freshwater bacterium in the order Burkholderiales. J Microbiol Biotechnol 19, 5-10.

16. Urdiain, M., López-López, A., Gonzalo, C., Busse, H.-J., Langer, S., Kämpfer, P. \& Rosselló-Móra, R. (2008). Reclassification of Rhodobium marinum and Rhodobium pfennigii as Afifella marina gen. nov. comb. nov. and Afifella pfennigii comb. nov., a new genus of photoheterotrophic Alphaproteobacteria and emended descriptions of Rhodobium, Rhodobium orientis and Rhodobium gokarnense. Syst Appl Microbiol 31, 339-351.

17. Vasil'eva, L. V., Semenov, A. M. \& Giniyatullina, A. I. (1991). A new species of soil bacteria of the genus Prosthecomicrobium. Microbiology (English translation of Mikrobiologiia) 60, 243-250. 